I I. Hippel, von.-_"Ist das Zusammenkommen von Mikrophthalmus congenitus und Glioma retinae im gleichem Auge sicher erwiesen?" Arch. f. Ophthal., Vol. LXI, p. 352, 1905.

12. Klein. - "Inversio iridis." Wiener Ophth. Gesellsch., I6 November, I9Io. Zeitschr. f. Augenheilk., Vol. XXIII, p. 280, 1910.

13. Mannhardt. - "Das Colobom der Aderhaut und seine Folgen." Arch.f. Ophthal., Vol. XLIII, p. 127, 1897 .

14. Natanson. - "Ueber Micropthalmus und Anopthalmus congenitus mit serösen Orbitopalpebralcysten." Arch.f. Ophthal., Vol. I.XVII, p. 185, 1908.

15. Kindfleisch. - "Beit. z. Entwicklungsgesch. der angeb. Missbildungen des Auges." Arch.f. Ophthal., Vol. XXXVII, Part iii, p. 192, 1891.

16. Seefelder.- "Entropium des Pupillarrandes." Ergebn. der allgem. Pathol., etc., p. 747,19 ro.

17. Spemann in Schwalbe._- "Die Morpholog. und die Missbild. des Menschen und der Thiere," Vol. III, f. ii, 1913.

18. Terrien. " Kyste rétro-oculaire et pseudo-microphtalmie." Arch: d'Ophthalm., Vol. XXXI, p. 787, 191 I.

\title{
INJURIES TO THE TROCHLEA
}

\author{
BY \\ A. S. Percival, M.A., M.B. Cantab., \\ SENIOR SURGEON EYE INFIRMARY, NEWCASTLE-UPON-TYNE.
}

ON several occasions the trochlea of the superior oblique has, unfortunately, suffered during surgical operations in its neighbourhood ; but, as far as I know, no case but one of my own has hitherto been reported of accidental damage to the trochlea. I have just seen a second case, and I think that if attention were directed towards its possibility, it would be found to be not so unusual as imagined.

My first case was reported in the Northumberland and Durham Medical Journal, 1898, in a paper on the Diagnosis of Ocular Paralyses.

The patient was a lady who, in 1895 , had received an accidental injury to her right eye from the point of a walking stick. A small scar was seen over the site of the trochlea, and she had all the symptoms of right superior oblique paralysis except the tilting of the false image. Thus, she had homonymous diplopia on looking downwards, with considerable depression of the false image on looking downwards and to the left. I considered that the fibrocartilaginous pulley had been torn from its situation and had reattached itself further back. In this way intorsion of the eye might only result when the muscle acted, so that there. would be no tilting of the false image. I saw the lady only a year ago with her husband, who had caused the injury, and found that the curious prismatic combination I had ordered her twenty years ago was still quite satisfactory.

Last week (May 31, 1919) I saw a boy at the Eye Infirmary who 
told me that four months ago he had fallen against a hook on a wall which had caught the lower part of his left eye. On the lower and inner part of the globe was a raised red patch close to the fornix. He had no pain, and his sight in that eye was excellent, but he had all the signs of left superior oblique paralysis which dated from the accident. There was neither any history nor any sign of injury about the upper and inner part of his orbit, but the site of the trochlea was distinctly tender to pressure.

I presume that the blow pressing the eye forcibly upwards and outwards put such a strain on the pulley that it tore.

As the diplopia did not seem to inconvenience him much except when he was reading, I advised him when looking down to tufn his head downwards and to the right, i.e., turning his head in the same direction as the affected muscle, if it acted, would turn his eye. $\mathrm{He}$ seemed to be quite satisfied with this as he could then read comfortably. I told him, if it made him tired, to wear a shade over one or the other eye.

Now, if a patient were not so easily satisfied, it is an interesting point to consider what should be done for him. It would be possible to detach a strip of periosteum from below and make a new pulley by attaching it to the adjoining periosteum, but it might not be strong enough. Prof. Morison, whom I consulted about this problem, suggested adding a little strip of fascia lata. I should be glad to hear of any other suggestions for the purpose, but I am afraid thàt, at any rate in my hands, the result would not be satisfactory to me, although some benefit might be derived.

Since writing the above I have seen, at the Eye Infirmary, another case of trochlear injury. A boy had been kicked by a horse on the right superciliary ridge; little damage resulted except for the complete detachment of his right trochlea, and the consequent inaction of his superior oblique.

\title{
MOBILE CYST OF THE IRIS
}

\author{
BY \\ Edgar Stevenson, \\ CAPTAIN R.A.M.C.
}

THE following account of a curious eye condition is put forward in the hope that it may of interest, though I am fully aware that a mere description of such a case is generally unconvincing. Unfortunately, however, owing to the patient's age and state of health, it is impossible to present her at any scientific meeting away from Liverpool. 